\title{
Sustainability of Chinese Culture in Moslems Society
}

\author{
Saiful Anwar Matondang and Febry Ichwan Butsi \\ Faculty of Education, Universitas Islam Sumatera Utara, Medan, Indonesia \\ Corresponding author: E-mail Addresses:saiful.matondang @fkip.uisu.ac.id
}

\begin{abstract}
Sustainability of ethnic culture in Southeast Asia has made the dramatically growth of ethnic identity. The ethnic revivals already made the increasing of cultural events in public spaces. This research paper sought the cultural sustainability of Chinese in Moslem society of Southaest Asia. A multisited ethnography was conducted in Medan Municipal of North Sumatra and Georgetown Penang, Malaysia to observe the sustained Chinese culture as the symbol of ethnification of Chinese in Moslems society in Southeast Asia region. It found that after 2003 Indonesia already saw the attractive cultural performances of Chinese in public spaces as the continuation of sustainability. In our ethnographic investigation from 2014 2017, the reshaping of the Chinese identity through sustainability of Chinese culture in Medan Municipality of North Sumatra, and Penang of Malaysia has the high public visibility. Research report showed the continuation of the Chinese rituals and festivals which were accompanied by music instruments of Chinese and theatrical performances. Those have been transformed from self commemorations to be more public; attractions already were moved to public places, not solely in temples or ethnic group surroundings as what commonly found in the past period. It concluded that the sustainability of Chinese culture in public spaces made the Southeast Asia connection among the Chinese groups solidify their identity in this region tightened.
\end{abstract}

Keywords: Sustainability; Chinese culture; Moslem society; Malaysia; Indonesia

\section{Introduction}

Sustainability of migrants' cultural events needs the new explanation and theories in Social Sciences. There is now a great attention of social scientists seeking the grounded theory of the dynamic reconstructions of ethnic identity, and building a model of ethnicity through the lenses of revivals (Matondang, 2016a). Nocca (2017) argued the sustainability development included cultural heritage of each ethnic group. The cultural sustainability which creates the ethnic revivals seems more visibel in public spaces. This study sought the Chinese cultural trends among Moslems society in Malaysia and Indonesia by making the exploration in wider contexts. This paper investigated the sustainability of Chinese culture among Moslems society in the Southeast Asian cities. It recorded that since colonial era some towns have been flooded by the migrants of South China, and they continued to make hybrid culture untill present globalization era. Furthermore, in globalizing world the Chinese groups in Malaysia and Indonesia, in the revival of ethnic identity, created a new form of Chinese cultural identity. The revival of Chinese culture in Malaysia was not only a matter of adopting the patterns of recommended cultural practices from the National Culture Policy, but it also had been creating a new hybrid culture among Chinese communities (Matondang, 2016a). Census repoted that in 2016, the Malaysian Chinese comprised about $23.7 \%$ of 31,7 million (the total population of Malaysia, stats.gov.my). In historical record, most of them migrated from southern China to Malaysia during the colonial period (late eigh-teenth to nineteenth centuries); during this time, the coloniser encouraged the recruitment of labourers 
from China and India (Siah, et all, 2015). The Chinese people have their own culture (Abidin et all, 2016).

Due to the paradigm changes in the Sustainable development; it now has shifted from economic oriented to social function (Mergos, George \& Patsavos, Nikolas, 2017) with an ethnographic investigation, the ethnic identities and the re-stylized global behaviors of the Malays and Straits Chinese was applied in study the Chinese in Indonesia and Malaysia. The indicated realities of ethnification process (Giordano, 2015 and Matondang, 2016b) of Chinese cultural sustainability led this research. Observed realities were to draw some new concepts of ethnic heritage through rituals and cultural performances. Thus, in the Straits of Melaka, the awareness of greatness of Culture of China already connected to "notion of Chinese as a marker of common culture and identity in a rapidly post-modernizing world" (Ang, 2001). It notes that the relationship of people of Chinese and Malacca is determined by two historical factors. The first reason is those who came to Malacca as a merchant, as recommended by the Chinese government. The second reason is through marriage that occurred between the Chinese who have long been settled in Malacca (Ismail \& Hassan, 2017). The link and business network of Straits Chinese in Asia Pacific region resulted in the ethnic identity reconstructions from colonial to global eras.

Additionally, the Chinese culture and business in Southeast Asia had been existing for centuries. The first generations came to the archipelago in Southeast Asia as merchants by sailing; since 1945, so called Indonesia has many Chinese immigrants as leaders of big companies. In establishing their business, the Chinese encountered not only other Chinese but also non-Chinese composed of hundreds of ethnic groups in Indonesia such as the Malays, the Javanese, the Sundanese, the Balinese, the Bataknese, the Minangkabaunese, the Bangkanese, the Banjarnese, the Bugisnese, the Manadonese, and others (Mulyana \& Zubair, 2015). The dynamic adjustment of Chinese identity made some constructions in ASEAN countries.

\section{Ethnicity Theory}

Research reports on the sustainability of ethnic groups via some formations; hybrid and mixed blood cases in some cities of Asian regional, have contributed on the ethnic studies in urban areas. The field reports of Indonesia and Malaysia showed that the revivals of Chinese culture resulted in the syncretism beliefs (popular) and hybrid of the culture identity of Straits Chinese. A model ethnification (Giordano, 2015) of Chinese identity made many times of readjustment process in the form of transformations as the ways to sustain the Chinese. Sustainability would be match within procession strategy of ethnic rituals (Turner, 1969). The highlighted cultural identity of the Straits Chinese in Indonesia and Malaysia made new regionall identity. Thus, Ang (2001) explained that there is a tremendously re-ethicized of Chinese in the last decade and so. In line with adaptation to colonial and independent governments, the Chinese took their identity to a new shape and transformed into reconstruction for regional experiences. The ethno-regionalism of Chinese shows newly forms in Medan and George Town (Matondang, 2016b).

The growing attention of Chinese in Southeast Asia to the cultural patrimony such as enacted rituals, symbolic actions and cultural performances might make sustainability of Chinese culture better. In anthropology of heritage intersects with the tourism (Nash, 2007; Bendix et all, 2012; Hitchcock \& King, 2010); closely related to the regional remodeled cultural heritage reproductions in two cities: Medan, North Sumatra of Indonesia and George Town Penang of Malaysia.

After the fall of New Order Regime in Indonesia, the descent of Chinese (mix blood) could celebrate Chinese rituals, carnivals and festivals performances freely. In public policy, the fourth President of Indonesia,his Excellency Abdurrahman Wahid in year 2000 gave an 
$3 \ldots$

opportunity to the Chinese group to get their rituals observance, and in 2003 the Chinese New Year has been official holiday in Indonesia. After 2003 Indonesia already saw the attractive cultural performances of Chinese in public spaces. In 2014 and 2017 observation, it was encountered the reshaping factor of the Chinese identity were the festivals in Medan of North Sumatra and Penang of Malaysia such as the Dragon dance, Lion Dance with the beating of gongs, cymbals, drums and the lighting of fire crackers and theatrical performance could be seen in public places now. The traditional ceremonies of Chinese New Year on February, Goddess of Mercy, Goddess of Earth, Tau Pek Kong and Goddes of Mazu were symbolized for the preserveded Chinese identity which also attracting tourists.

The new way of enacting rites of passage in dramatization as socio-cultural changes appared in Asian context, and it is very necessary to take numerous of symbolic interpretative theories in investigating the symbolic meanings. It was taken such as theories of social actions in cultural milieu of the ethnographic works of Goffman (1956), Singer, Schechner and Geertz in Balinese. Those had been applied to support the obtained data analysis. Those theoretical foundations had been adopted in this comparative cultural research. The foundations direct the fieldwork which was searching the enactments of rituals and cultural performances by the Chinese communities in Medan and Penang, Malaysia.

Therefore, the rituals, carnivals and festivals of Chinese communities were assumpted as the potential anthropological subjects in symbolic interpretative perspective; consequently the Chinese rituals and cultural performances for ethnic identity sustainability together with heritage that had been studied throughly indicated the ethno-regional shaping. The anthropological materials of Chinese culture in Medan and Penang which have been reappeared in the forms of ethnic sustainability evently magnified in Asian countries. The ethnic sustainability makes the newly cultural phenomenon; the rites of passage, transformations, and experiences of communities (Turner, 1987).

\section{A Multisited Ethnography}

Ethnographic field work now has extended from one location to many sites (places). It is so called multi-sited technique or ethnography (Marcus, 1995). A participant observation was carried out for collecting data of the enactments of rituals and festivals of Chineseness in Southeast Asia with a multi-sited ethnography. The rituals and festivals were used as media to solidify the social groups and to highlight the ethnic identity among Straits Chinese in the sister cities of Medan and Penang. The observation for recording of a series of acts which maximize the symbols for social and political attentions where the Straits Chinese make ethnification of symbolic actions through rituals and festivals in public spaces in new year celebrations. The singing, dancing, joking, and laughing assigned the cultural symbols in the cultural contexts and references of shared beliefs and myths.

The ethnic culture of Chinese in Moslems society of Southeast Asia in a multisited ethtnography was to explore for collecting the sustainability process in the rituals and celebrations. In collecting data with a multisited technique, the framework of rites of passage from the breach, liminal (betwixt), redress to reintegration was adopted. A multisited technique (Marcus, 1995) guided the observation on the symbolic actions ; as observers monitor the stages in which cycles of rituals and cultural enactments are performed by the community. It was targeting manifestations of human beliefs and shared myths and experiences in the communities though symbolic analysis. Thus, Amigó\& Unakafova (2015) argued that the symbolic representation was an efficient technique in time series analysis. Each event of symbolic representation must be simpler to analyze than the original time series. The techniques applied to collect data included four paths; namely: (1). seeking the ethno-history of Straits Chinese; (2). making a survey in Medan and George Town Penang; 
(3). doing some iinterviews and, (4). Observing the sustained rituals and festivals of the Straits Chinese.

\section{Chinese Identity in Muslim Dominant Countries}

Colonial policy has made the Chinese migration to Southeast Asia and it has resulted in the complicated ethnic plurality. Indonesia and Malaysia as the hosts of Chinese migrants have been flooded with Chinese cultural practices since colonial era. Now the Chinese descendants continue their great grandparents' heritage. Sustainability of Chinese culture in Penang of Malaysia and Medan of Indonesia reshapes the formation of society. The colonial policies made the plural society appear in urban areas. The present shows of Chinese cultural celebrations in public places made a new thing in those two cities. The plural society is more visible; in colonial era and new independent period only gave the Chinese community to enact rituals and festivals of Chinese in limited areas.

Present phenomenon of Chinese culture in Moslems society of Penang and Medan make use of heritage as potential subject of Chinese identity. Therefore, heritage as a past experience must be recreated and reclaimed to have a contextual meaning in the present (Turner, 1986). Seeking the identity through heritage enactments in the forms of rituals and celebrations appear more frequent in Malaysia and Indonesia among Chinese communities. Thus, the heritage has been reconstructed for the sake of ethnic identity; heritage reproductions have been transformed into instruments for political, ecenomic and tourism goals. Here specifically the cultural heritage reproductions were aimed to reconstruct identity and tourism sector more ofdten found in public spaces. The rituals, ceremonies, carnivals and festivals in ethnographical fieldwork are collected as primary data of various civilizations (Turner, 1983). The social drama paradigm in the symbolic interpretative anthropology not only addresses to the phenomenon of social actions that celebrated in rituals or in cultural performances seasonally or annually by the small ethnic groups to revitalize the past experiences, nevertheless right now the enactments also assigned to explore the symbolic meanings of invented festivals.

It was Van-Gannep who had a strong influential intellectual foundation for the festivals. Further, Tuner was inspired by the rites of the passage of Van-Gannep; the passage from the birth, liminal or betwixt, marriage and to the death is on the theatrical paths of Van-Gannep, 2004) and Turner named this theory as social drama. In the fieldwork, when the observation towards enactments of the rituals and celebrations of the Malays and Straits Chinese in George Town Penang of Malaysia and of Medan North in Sumatra of Indonesia was carried out, the adjusted theory of Victor W Turner's social drama which stresses on the breach, luminal or betwixt and redress or recovery and reintegration. Data obtained revealed that in Chinese tradition, the Spring Celebration is rightly from the first day of the Lunar New Year of Chinese until the fifteenth day. In Malay Tradition, the Muslims celebrate as the winning Day after one month had a fasting without food and drink from the dawn to the Sun set. Also the ancient heritage Malay Ahoi Paddy Harvest celebration in Deli of North Sumatra was followed the Malay farmers tradition.

It noted that the ethnic identity revivals in regional and global scopes (Matondang, 2016a) bring the rites of passage to a wider context of sustainability. The ethno-regionalized the Chinese culture were manifested in the cultural sustainability. This tendency made Chinese groups seek the symbolic meanings and their social functions of Chinese festivals. The rising of the rituals and living performances of Chinese in Medan and Penang for sustainability might be well-known as traditional ways of life (Hitchcock \& King, 2009). 
$5 \ldots$

The centers of rituals and tourist attractions used the best moments of cultural sustainability of Chinese in Penang and Medan of North Sumatra.

It was known that Schechner (2006) who developed in the processual way to experience the structuring social institution of a community (Turner, 1987). In practice, the way of Malays and Straits Chinese in revived ethnic identity and got it in sustaining the social existence. The present enactments of rituals and celebrations and the new directions of Chinese culture in the historical background of ethnic groups (Giordano, 2015) were very supportive.

The Chinese folks in Malaysia and Indonesia have sustained the usage of local Chinese vernaculars, the Mandarin and English in Southeast Asia. The third and fourth generations preferred national identity of China (Mandarin) and international (English) instead of local Chinese dialects of Cantonese, Hakka, or Hokiens. It was found that many Straits Chinese associations and the Chinese clubs created the regional identity in Southeast Asian region after 1980's. Chinese descendants in this region learned more Mandarin and Chinese heritage in the forms of sports, arts and entertainments. Also the promotions to travel to China mainland enhance a number of packages for visiting great grand parents origins. It was found that then the Chinese associations and films distributions arising in Southeast Asia. Thus, (Ang, 2001) retold her own experience as Chinese diaspora in Holland had watched some Chinese movies that she didnot know before (Ang, 2001).

Data obtained display that the Chinese culture has been sustained through various media and the rites of passage in Medan of North Sumatra and George Town of Malaysia; celebrated by enacted ceremonies with symbols. It is very suitable if this study was searching the symbolic meanings (Turner, 1985; Geertz, 1988) of rituals and celebrations in a new way, for marking the cycles of life in the stages of breach, liminal, redress and reintegration(Turner, 1985). The Straits Chinese of Medan of North Sumatra and Malaysia made some ethnification formations of Chineseness that were observed and explored by symbolic anthropology.

Chinese culture cycles in two cities were correlated with the growing the revival of ethnic identity in this regional area. The awareness of identity of urban Chinese was getting growth in dynamic process. The forms of rituals and entertainments had ben put into the potential human experiences that reached the regional and global interactions. The selected cultural patrimony and the dramatization made the ethnification process emerged to be the potential cultural heritage of two cities, George Town of Malaysia and Medan of Indonesia. Those were found crystalized culture led into a social cycle. It was recorded that the Chinese shared beliefs or popular myths supported the enactments of rituals and festivals of the Strait Chinese were to be instruments for the Chinese ethnification regionally.

The observation on the sustainability reported that the rituals and celebrations of Chinese in Southeast Asia that enacted annually revealed through symbols and their meanings. Data obtained were mapping out the rites which manifested in the rituals, festivals, celebrations. Those have been the living in heritage which attracted the touriststs come to see the events. Festivals in this study were selected as subject of the ethnic reconstructions. The process of using Chinese solidarity in Southeast Asia makes the ethnic identities tied to the annually cycles of religions, customs, and heritage events in national and regional levels. The explored the rituals and festivals are a part of new born cultural system; the webs of significations between the folks' actions in rituals and in celebrations. The Chinese ethnification was involving the performers, art forms, ethnic community as audience, and atmosphere as well as tourists.

It was found the transformations of the local traditions with innovative performances for linking the identity sustainability to the regional and global situations; the attention is 
paid to cycles, spaces, momentums of the Malays and Straits Chinese rituals and cultural performances. So the rituals and cultural performances were collected from the direct observation, interviews with organizers, the key persons in rituals, the officials of tourism board, associations of travel agents and hotels, academicians and journalists. Especially for data collection in George Town, besides the observation, also this study gathered documrents from the archives. It was noted that the George Town World Heritage Incorporated (GTHWI) and Penang Heritage Trust in Penang since the $7^{\text {th }}$ of July 2008 helped Chinese community to preserve the heritage. Thus, the state and GTHI prepared the UNESCO heritage safeguard regime in managing cultural heritage and it was found this policy more or less is moderator variable in this study.

It is noted that the heritage as the source of ethnic identity reconstructions now has connected to regional and global scopes. The interrelations of localism, regionalization and globalization are addressed through fieldwork and data obtained are analyzed by looking at local, regional, and global integration. The meanings of cultural performances and power as well as ideology in the reconstructions of ethnic identities by the Malays and Straits Chinese in Medan and Penang are observed and interpreted by considering the interaction of local, regional and global contexts. The data of the symbolic meanings and functions of rituals and cultural performances of the Malays and Straits Chinese that have been collected would be used for constructing the interrelation of local, regional and global through cultures. "A wave ethnification resulting in a cultural and political fragmentation of formerly larger units" (Friedman, 2000). The cultural performance is conceptualized based on the massively decentralization and renewed politicized identities of the Malays and Straits Chinese in Medan and Penang. In social interactions, it enforces the sustainability perspective should be brought into regional and global scopes. In addition to the currently cultural studies, the expected theory which elaborates the sustained Chinese ethnic in the form of heritage reproductions for the regional have contributed in explaining the Chinese cultural events in public spaces.

\section{Conclusions}

The Chinese culture sustainability in Moslems society of Southeast Asia shows a new phenomenon. The sustainability of ethnic identity of the Chinese descendants in two cities; Medan of North Sumatra and George Town of Malaysia indicated that rituals and festivals have been the effective media to uphold the identity in this region. Many rituals and festivals of urban Chinese have been enacted in public places to solidify the Chinese ethnic and the power to have rights in Indonesia and Malaysia. Also sustainability makes the reauthentication, revitalization, recreation of the potential cultural heritage by Chinese groups in Moslems society of Southeast Asian region have created a newly cultural phenomenon.

\section{References}

Amigó, J. M., Keller, K., \&Unakafova, V. A. 2015.Ordinal symbolic analysis and its application to biomedical recordings.Phil. Trans. R. Soc. A, 373(2034), 20140091.

Abidin, M. Z. H. Z., Habidin, N. F., Salleh, M. Y. Y., Hassan, P., Yaacob, H. R. M., Yaacob, M., \& Noh, A. M. M. 2016. Assimilation of the Malay Culture towards the Straights of Chinese Community in the State of Kelantan: Study in Kampung Pasir Parit, Chetok, Pasir Mas, Kelantan. International Journal of Academic Research in Business and Social Sciences, 6(11), 38-51.

Ang, Ien. 2001.On not Speaking Chinese, living between Asia and the West, Routledge: USA and Canada 
$7 \ldots$

Bendix, Regina F, AdityaEggert, Arnika Peselmann.2012Eds. Heritage Regimes and the State, Universitäts verlag Göttingen

Department of Statistics Malaysia.2016. Current Population Estimates, Malaysia 2014-2016, stats.gov.my

Friedman, J. 2000. Globalization, class and culture in global systems.Journal of worldsystems research, 6(3), 636-656.

Geertz, Clifford. 1988. Works and Lives: The Anthropologist as Author, Stanford University Press

Giordano, Christian. 2005. The Past in the Present: Actualized History in the Social Construction of Reality. In H. T. Don Kalb, Critical Junctions. Anthropology and History beyond the Cultural Turn New York \& Oxford: Beghahn. pp. 53-71

Giordano,Christian.2015. Power, Legitimacy, Historical Legacies, A Disenchanted Political Anthtopology, Lit Verlag: Zurich

Goffman, Erving. 1956. The Presentation of Self in Everyday Life. Edinburg: Social Science Research Centre: University of Edinburg.

Hitchcock, M, King, V T and Parnwell, M.2009. Tourism in Southeast Asia: Challanges and New Directions, Honolulu: The University of Hawaii Press.

Hitchcock, M, King, V T and Parnwell, M.2010. Heritage Tourism in Southeast Asia Honolulu: The University of Hawaii Press

Ismail, S., \& Hassan, M. S. 2017.Chinese Decor and Motifs in the Interior Decoration: A Study on the Old Mosque in Malacca in the Early 18th Century. Jurnal ILMI, 7(1).

Marcus, E George .1995. Ethnography of /in World system:The Emergence of Multisite

Ethnography, Annual Review of Anthropology 1995 24:1, 95-117

Matondang, SA. 2016a. The Revival of Chinesesness as cultural indentity in Malaysia, Khazar Journal of Humanities and Social Sciences, Vol 19 No 4 Dec 2016,pp.50-57.

Matondang, SA.2016b. The ethno-regional social dramas of Southeast Asian in globalism: recasting cultural heritage for ethnic revivals, University of Fribough: Switzerland.

Mergos, George \& Patsavos, Nikolas. 2017. Cultural Heritage and Sustainability Development:Econmic Benefits, Social Opportunities and Policy Challenges, Technical University of Crete.

Mulyana, D., \& Zubair, A. 2015. Intercultural communication competence developed by Chinese in communicating with Malays in Bangka Island, Indonesia. Sino-US English Teaching, 12(4), 299-309.

Nash, Dennisson. 2007. The Study of Tourism Anthropogical and Sociological Beginnings,UK: Emerald Group Publishing

Nocca, Frances. 2017. The Role of Cultural Heritage in Sustainable Development: Multidimensional Indicators as Decision-Making tool. Sustainability, 9.1882.

Schechner, R. 2006. Performance Studies: An Introduction, Second Edition. New York: Routledge

Siah, P. C., Ong, S. B. C., Tan, S. M., \& Sim, C. P. 2015. Perception on Chinese values: A comparison of Chinese secondary students studying at national secondary schools and Chinese independent schools in Malaysia. The Social Science Journal, 52(1), 62-68.

Turner, V.W. 1969. Liminality and communitas. The ritual process: Structure and antistructure, 94, 130.

Turner, V W. 1987. Anthropology of Performance.New York: PAJ Publication

Turner, V W.1986. The Anthropology of Experience. Illinois Urbana: Illinois University Press. 
Turner, V W. 1983. Carnival in Rio: Dionysian Drama in an Industrializing Society. In F. E. Manning, The Celebration of the Society: Perspectives on Cultural Performance. Bowling Green: Bowling Green University Press

Van-Gennep, A. 2004.The Rites of Passage (Reprinted Version).London: Routledge

Turner, Victor W. 1985.On the Edge of the Bush Anthropology as Experience, Arizona University Press 